\title{
Toxicological assessment of pesticide contaminated soils with use of biotests
}

\author{
Tomasz Baczyński ${ }^{1}$, Anna Małachowska-Jutsz², Ewa Szalińska³ \\ ${ }^{1}$ Cracow University of Technology, Faculty of Environmental Engineering, Institute of Water Supply and Environmental \\ Protection; ul. Warszawska 24, 31-155 Krakow; e-mail: tomaszb@vistula.wis.pk.edu.pl \\ ${ }^{2}$ Silesian University of Technology, Faculty of Energy and Environmental Engineering, Department of Environmental \\ Biotechnology; ul. Akademicka 2, 44-100 Gliwice; e-mail: Anna.MalachowskaJutsz@polsl.pl \\ ${ }^{3}$ AGH University of Science and Technology, Faculty of Geology, Geophysics and Environmental Protection, \\ Department of Environment Protection; al. A. Mickiewicza 30, 30-059 Krakow; e-mail: eszalinska@agh.edu.pl.
}

(C) 2018 Authors. This is an open access publication, which can be used, distributed and reproduced in any medium according to the Creative Commons CC-BY 4.0 License requiring that the original work has been properly cited.

Received: 14 March 2018; accepted: 8 May 2018

\begin{abstract}
The paper presents the results of experiments on ecological toxicity assessment performed for 12 soil samples collected at 3 obsolete pesticide "tombs" in Poland, before their final disposal. Bioavailability of the main pollutants: p,p'-DDT, lindane and methoxychlor was assessed for selected samples by consecutive solid phase extraction using a Tenax TA sorbent. Several toxicity bioassays were also carried out, including: reducers (Microtox Soild Phase), producers (Phytotox) and consumers (tests of avoidance, acute toxicity and reproduction with use of the earthworm Eisenia foetida). Data from toxicity tests were discussed against the results of the chemical analysis of a wide range of pesticides determined by GC-ECD and GC-NPD. This part of the study enabled the evaluation of the applicability of the aforementioned bioassays in the assessment of pesticide soil pollution. Results of toxicity tests showed a slight to severe impairment of habitat function for all of the contaminated samples, which was only partially reflected by the analytical data. The most sensitive biotest was earthworm reproduction, followed by Phytotox and earthworm acute toxicity. Earthworm avoidance and Microtox tests were found to be of rather limited usability.
\end{abstract}

Keywords: soil toxicity, bioassays, obsolete pesticides, bioavailability

\section{INTRODUCTION}

Exposure to obsolete pesticides is regarded as inducing several adverse effects on human health and the environment (Odukkathil \& Vasudevan 2013, Kim et al. 2017). Many of these chemicals are classified as Persistent Organic Pollutants (POPs).

The problem of environmental pollution by obsolete pesticides, such as p,p'-DDT, $\gamma-\mathrm{HCH}$ (lindane), etc., in Poland is commonly associated with the so-called pesticide "tombs" - provisional deposit sites - widely constructed over the country in the period of 1965-1989 (Gałuszka et al. 2011). The disposal of these sites was planned, according to the National Waste Management Plan, to be accomplished by the year 2010. In reality, this action was delayed at least until year 2012, when almost all of the 242 identified tombs had been reclaimed. As of year 2016, only three sites remained undisposed (MŚ 2016), supposedly due to legal and proprietary issues. In the report prepared by the Polish Supreme Audit Office (NIK 2012), the general assessment of disposal activities was quite positive, however there were also several objections raised. They pointed to an insufficient monitoring of the already reclaimed sites, and a very small effort put into searching for so far unidentified tombs. 
Another place known for heavy pollution by obsolete pesticides is the industrial landfill "Rudna-Góra" at the chemical factory in Jaworzno. Among the 160,000 tons of stored waste, there are huge amounts of byproducts from pesticide production. They include DDT and its metabolites, $\mathrm{HCH}$ isomers, and other chemicals. These compounds are released, by uncontrolled surface runoffs and groundwater flow, into the tributaries of the upper Vistula River.

Apart from the above mentioned hot-spots, there are several locations in Poland where monitoring activities demonstrate exceedances of pesticide soil quality standards. In a 2015 year sampling campaign for "chemistry monitoring of arable soils in Poland" (Siebielec et al. 2017) 14 samples out of 216 (6.5\%) showed p,p'-DDX concentration (sum of $\mathrm{p}, \mathrm{p}^{\prime}-\mathrm{DDT}$ and its primary metabolites p,p'-DDD and -DDE) above $0.12 \mathrm{mg} / \mathrm{kg}$, which is the value currently permitted for the surface layer in agricultural areas in Poland (Rozporządzenie 2016). The highest reported value in this study was $0.48 \mathrm{mg} / \mathrm{kg}$. Also, among the 693 samples collected in year 2013 for the Atlas geochemiczny Warszawy i okolic (Geochemical atlas of Warsaw and Environs) (Bojakowska et al. 2018) 27 (3.9\%) did not meet even the highest Polish standard for $\mathrm{p}, \mathrm{p}$ '-DDX content in the surface soil, that is $0.25 \mathrm{mg} / \mathrm{kg}$, permitted for industrial areas (the maximum found was $5.4 \mathrm{mg} / \mathrm{kg}$ ). It was stated that $22.5 \%$ of all the collected samples contain less than $0.0025 \mathrm{mg} / \mathrm{kg}$ p,p'-DDX; $44.7 \%$ between 0.0025 and $0.025 \mathrm{mg} / \mathrm{kg} ; 23.1 \%$ between 0.025 and $0.12 \mathrm{mg} / \mathrm{kg}$ and $5.8 \%$ between 0.12 and $0.25 \mathrm{mg} / \mathrm{kg}$. However, the authors did not classify the samples in terms of the actual usage of the investigated area, which is crucial for establishing the allowable level of contamination under the current Polish legislation. Taking into consideration that many of the samples were probably taken in living and recreational areas, which fall under the Rozporządzenie (2016) ordinance into group I (with permissible concentrations of $0.0025 \mathrm{mg} / \mathrm{kg}$ p,p'-DDX), it may be expected that the real number of samples not fulfilling the present soil quality standards was much higher.

According to the Polish Environment Protection Law (Ustawa 2018) soils with contaminant concentrations above the respective permissible values have to be remediated. In case of e.g. DDT, or other obsolete chlorinated pesticide pollution, effective and proven remediation technologies are scarcely available (Baczyński 2010). The only way of avoiding such costly and complicated actions is to demonstrate that a significant risk for human health or the environment does not occur. The exact procedure of such environmental risk assessment has not yet been specified in the Polish legislation. However, in its general guidelines (Ustawa 2018) it is stated that such procedure must include tests of contamination bioavailability, the possibility of spreading, etc. Procedures applied in other countries, such as the Dutch TRIAD method (Jensen \& Mesman 2006), also use the results of ecological observations and toxicity bioassays.

The paper presents an application example of different tools to assess the ecological toxicity of soils in the areas adjacent to pesticide tombs. The experimental scope included the bioavailability measurements of the main contaminants: p,p'DDT, lindane, and methoxychlor, by sequential solid phase extraction using a Tenax TA sorbent. Also, several toxicity bioassays, covering reducers (Microtox Solid-Phase test), producers (Phytotox test), and consumers (tests of avoidance, reproduction and acute toxicity using earthworms) have been used. Results of biotests were compared with the results of chemical analyses, which enabled the evaluation of their usability in the assessment of soil pollution by obsolete pesticides. Some of these results have already been addressed in partial publications (Małachowska-Jutsz et al. 2007a, 2007b, 2008, Baczynski et al. 2012). However, this is the first attempt to present and summarize the whole investigation, including also a considerable part of data which are presented for the first time.

\section{METHODS}

Soil samples were collected at three pesticide "tombs" (the precise localization of the tombs is available at: SIDoM 2010): Sepno-Radonia, Bogumiłów (both in the Łódź voivodeship, further labeled as SEP and BOG), and Młynów (Greater Poland voivodeship, labelled as MLY). Sampling was done manually, using a shovel, from the bottom of excavation pits made during the final disposal of 
the tombs, from contaminated areas close to or below the tombs' chambers, $2-4 \mathrm{~m}$ below the original ground level (Fig. 1). For each tomb, three samples were selected for testing (sample labels: Sepno-Radonia - SEP2, SEP4, SEP5; Bogumiłów - BOG3, BOG4, BOG5; Młynów - MLY2, MLY3, MLY4). Every time one additional sample was taken at some distance from the tomb, in a supposedly uncontaminated area, 1-2 m below the ground level, to serve as a background control (SEP02, BOG02 and MLY02 respectively). Before testing, samples were sieved through a $2 \mathrm{~mm}$ sieve, air dried, and in cases of prolonged storage, refrigerated. Bioassays were performed in series, separately for each site. In each series, two types of controls were used for tests with plants (Phytotox) and earthworms: background samples, mentioned above, and the artificial soil (REF). The latter comprised of 70\% coarse sand, 20\% kaolin clay, 10\% Sphagnum peat, with a $\mathrm{pH}$ adjusted to 6 with $\mathrm{CaCO}_{3}$ (PN-ISO 11268-1, also OECD 207 and 222).

With reference to texture, soils from BOG and MLY could be generally regarded as sand (according to USDA classification), with a few percent of silt and clay weight fractions, and a small content of organic fraction $(<1 \%)$. SEP soils were different, containing high fractions of silt and clay, thus representing sandy clay loam or clay loam. Samples were analyzed for a wide range of pesticides (Tab. 1). Organochlorine, organophosphorus compounds, nitrophenols and triazines were extracted from $20 \mathrm{~g}$ of each soil sample by shaking for $30 \mathrm{~min}$ with $100 \mathrm{ml}$ of acetone and $1 \mathrm{ml}$ of distilled water. Filtered extract was extracted twice with $100 \mathrm{ml}$ and then $50 \mathrm{ml}$ of dichloromethane. After drying with anhydrous sodium sulfate, the extract was evaporated and residue was dissolved with $2 \mathrm{ml}$ of acetone. For phenoxy acid herbicides, $20 \mathrm{~g}$ of soil was shaken for $30 \mathrm{~min}$ with $100 \mathrm{ml}$ of dichloromethane, acidified with $10 \mathrm{ml}$ of $25 \%$ sulfuric acid, and shaking was continued for a further $30 \mathrm{~min}$. Dewatered extract was evaporated to dryness, and the residue was dissolved in $5 \mathrm{ml}$ of acetone. Derivatization was executed with $30 \mu \mathrm{l}$ pentafluorobenzyl bromide and $3 \mathrm{ml}$ of $10 \%$ triethylodiamine for $12 \mathrm{~h}$. The extract was evaporated to $1 \mathrm{ml}$ under nitrogen, then $1 \mathrm{ml}$ of hexane and $2 \mathrm{ml}$ of isooctane were added, and again evaporated to $1 \mathrm{ml}$. For analysis, extracts were dissolved according to GC calibration range. GC analyses were made on a Hewlett-Packard 5890 GC with nitrogen as the carrier gas. Organochlorines and phenoxy herbicides were determined using ECD with a HP-1 capillary column. Organophosphorus compounds, nitrophenols and triazines were determined using a NPD and HP-5 capillary column. Dithiocarbamates were determined spectrophotometrically. $100 \mathrm{~g}$ of soil was boiled with $200 \mathrm{ml}$ of water and $60 \mathrm{ml}$ of 1:1 $\mathrm{HCl}$. The evolved carbon disulfide was adsorbed as a copper complex of N,N-bis-(2-hydroxyethylo)-dicarbamate, measured at $435 \mathrm{~nm}$ wavelength.

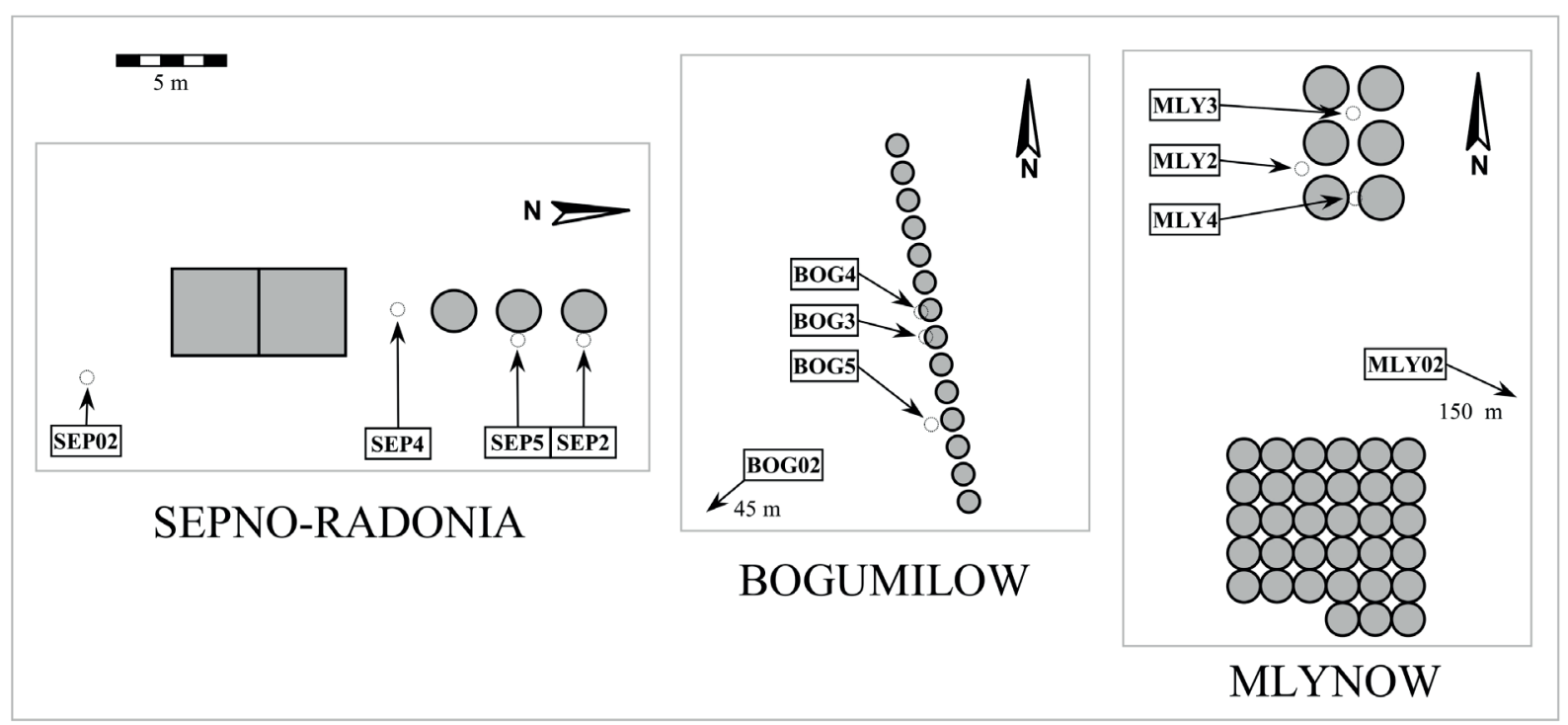

Fig. 1. Schemes of sampling points in relation to tombs' chambers 
Table 1

Results of the analytical determination of pesticide residues in the investigated soil samples

\begin{tabular}{|c|c|c|c|c|c|c|c|c|c|c|c|c|}
\hline & 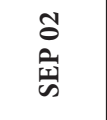 & $\frac{N}{\hat{y}}$ & $\begin{array}{l}\stackrel{+}{ } \\
\vec{s}\end{array}$ & $\begin{array}{l}\text { in } \\
\text { 芴 }\end{array}$ & $\begin{array}{l}1 \\
\delta \\
0 \\
0\end{array}$ & $\begin{array}{l}\infty \\
0 \\
0\end{array}$ & $\begin{array}{l}+1 \\
0 \\
0\end{array}$ & $\begin{array}{l}\text { in } \\
0 \\
0\end{array}$ & 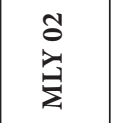 & $\underset{\Sigma}{\stackrel{N}{Z}}$ & $\stackrel{m}{=}$ & $\stackrel{+}{\stackrel{H}{Z}}$ \\
\hline \multicolumn{13}{|c|}{ organochlorines } \\
\hline p,p'DDE & 0.005 & 5.250 & 0.980 & 0.320 & 0.002 & 0.007 & 0.070 & 0.015 & $<0.005$ & 0.030 & 0.311 & 0.161 \\
\hline p,p'DDD & 0.006 & 7.320 & 0.780 & 0.820 & $<0.005$ & 0.025 & 0.268 & 0.070 & 0.010 & 2.00 & 4.65 & 2.90 \\
\hline o,p'DDT & $<0.005$ & 4.370 & 0.530 & 0.320 & 0.003 & 0.059 & 0.178 & 0.242 & 0.008 & 4.04 & 32.0 & 16.4 \\
\hline p,p'DDT & 0.033 & 31.80 & 3.000 & 2.700 & 0.009 & 0.205 & 0.517 & 0.738 & 0.019 & 3.50 & 129.0 & 52.0 \\
\hline $\mathrm{p}, \mathrm{p}^{\prime} \mathrm{DDX}^{\star}$ & 0.044 & 44.37 & 4.76 & 3.84 & 0.014 & 0.237 & 0.855 & 0.823 & $<0.034$ & 5.53 & 134.0 & 55.1 \\
\hline aldrin & $<0.01$ & $<0.01$ & $<0.01$ & $<0.01$ & $<0.01$ & $<0.01$ & 0.044 & $<0.01$ & $<0.002$ & 0.003 & 0.020 & $<0.002$ \\
\hline dieldrin & $<0.005$ & $<0.005$ & $<0.005$ & $<0.005$ & $<0.005$ & $<0.005$ & $<0.005$ & $<0.005$ & $<0.001$ & 0.018 & 0.230 & $<0.001$ \\
\hline endrin & $<0.005$ & $<0.005$ & $<0.005$ & $<0.005$ & $<0.005$ & $<0.005$ & $<0.005$ & 0.035 & $<0.005$ & 0.049 & 0.166 & 0.092 \\
\hline$\alpha-\mathrm{HCH}$ & $<0.005$ & $<0.005$ & $<0.005$ & $<0.005$ & 0.002 & 0.002 & $<0.002$ & $<0.002$ & $<0.003$ & $<0.003$ & 0.138 & 0.119 \\
\hline$\beta-\mathrm{HCH}$ & $<0.005$ & $<0.005$ & $<0.005$ & $<0.005$ & $<0.005$ & $<0.005$ & $<0.005$ & $<0.005$ & $<0.005$ & 0.013 & 0.013 & $<0.005$ \\
\hline$\gamma-\mathrm{HCH}$ & 0.014 & 4.440 & 0.143 & 0.980 & 0.004 & 0.029 & 0.686 & 0.028 & $<0.005$ & 0.337 & 2.50 & 0.783 \\
\hline hexachlorobenzene & $<0.005$ & $<0.005$ & $<0.005$ & $<0.005$ & 0.002 & 0.004 & 0.132 & 0.003 & $<0.005$ & 0.006 & 0.068 & 0.039 \\
\hline methoxychlor & $<0.01$ & 3.00 & $<0.01$ & 0.660 & $<0.01$ & 0.026 & 0.531 & 0.216 & $<0.01$ & 0.500 & 4.20 & 5.00 \\
\hline heptachlor & NA & NA & NA & NA & NA & NA & NA & NA & $<0.005$ & 0.009 & $<0.005$ & 0.006 \\
\hline \multicolumn{13}{|c|}{ organophosphates } \\
\hline chlorphenvinphos & $<0.2$ & $<0.2$ & $<0.2$ & $<0.2$ & $<0.01$ & 0.019 & 0.234 & $<0.01$ & $<0.02$ & $<0.02$ & 0.050 & $<0.02$ \\
\hline dimetoat & $<0.1$ & $<0.1$ & $<0.1$ & $<0.1$ & $<0.1$ & $<0.1$ & 1.46 & $<0.1$ & $<0.02$ & $<0.02$ & $<0.02$ & $<0.02$ \\
\hline fenitrotion & $<0.05$ & $<0.05$ & $<0.05$ & $<0.05$ & $<0.02$ & $<0.02$ & 0.407 & $<0.02$ & $<0.01$ & $<0.01$ & $<0.01$ & $<0.01$ \\
\hline fention & $<0.1$ & $<0.1$ & $<0.1$ & $<0.1$ & $<0.1$ & $<0.1$ & 0.350 & $<0.1$ & $<0.01$ & $<0.01$ & 0.052 & $<0.01$ \\
\hline formothion & $<0.05$ & $<0.05$ & $<0.05$ & $<0.05$ & $<0.05$ & $<0.05$ & $<0.05$ & $<0.05$ & $<0.01$ & $<0.01$ & 0.452 & $<0.01$ \\
\hline pyrimiphos methyl & $<0.1$ & $<0.1$ & $<0.1$ & $<0.1$ & $<0.1$ & $<0.1$ & $<0.1$ & $<0.1$ & $<0.005$ & $<0.005$ & 0.013 & $<0.005$ \\
\hline parathion & $<0.05$ & $<0.05$ & $<0.05$ & $<0.05$ & $<0.05$ & $<0.05$ & 0.076 & $<0.05$ & $<0.02$ & $<0.02$ & $<0.02$ & $<0.02$ \\
\hline \multicolumn{13}{|c|}{ nitrophenols } \\
\hline dinoseb & $<0.2$ & 0.590 & $<0.2$ & 0.350 & $<0.2$ & $<0.2$ & 1.70 & $<0.2$ & $<0.05$ & $<0.05$ & $<0.05$ & $<0.05$ \\
\hline DNOC & $<0.2$ & 3.80 & 0.284 & $<0.2$ & $<0.2$ & $<0.2$ & $<0.2$ & $<0.2$ & $<0.05$ & 6.40 & 6.90 & 3.60 \\
\hline \multicolumn{13}{|c|}{ triazines } \\
\hline simazine & $<0.1$ & 0.920 & 0.110 & 0.413 & $<0.1$ & $<0.1$ & $<0.1$ & $<0.1$ & $<0.01$ & $<0.01$ & $<0.01$ & $<0.01$ \\
\hline \multicolumn{13}{|c|}{ carbamates } \\
\hline pyrimicarb & $<0.1$ & $<0.1$ & $<0.1$ & $<0.1$ & $<0.1$ & $<0.1$ & 0.123 & $<0.1$ & $<0.005$ & $<0.005$ & $<0.005$ & $<0.005$ \\
\hline propoxur & $<0.1$ & $<0.1$ & $<0.1$ & $<0.1$ & $<0.1$ & $<0.1$ & $<0.1$ & $<0.1$ & $<0.05$ & 0.476 & 1.53 & $<0.05$ \\
\hline chloropropham & $<0.1$ & 2.330 & $<0.1$ & 0.600 & $<0.1$ & $<0.1$ & $<0.1$ & $<0.1$ & $<0.01$ & $<0.01$ & $<0.01$ & $<0.01$ \\
\hline dithiocarbamates\# & $<0.1$ & 16.80 & 0.840 & 8.80 & $<0.1$ & $<0.1$ & $<0.1$ & $<0.1$ & $<0.1$ & $<0.1$ & 3.00 & 3.96 \\
\hline \multicolumn{13}{|c|}{ phenoxy acids } \\
\hline $2,4-\mathrm{D}$ & $<0.05$ & 9.60 & $<0.05$ & 1.90 & $<0.05$ & $<0.05$ & $<0.05$ & $<0.05$ & $<0.02$ & $<0.02$ & $<0.02$ & $<0.02$ \\
\hline MCPA & $<0.05$ & 3.20 & $<0.05$ & 1.00 & $<0.05$ & $<0.05$ & $<0.05$ & $<0.05$ & $<0.02$ & 0.153 & 0.035 & 0.048 \\
\hline \multicolumn{13}{|c|}{ others } \\
\hline chlorfenson & $<0.01$ & $<0.01$ & $<0.01$ & 0.340 & $<0.01$ & 0.024 & 0.594 & 0.012 & $<0.01$ & 0.044 & 0.099 & 0.061 \\
\hline quintozene & $<0.01$ & 0.730 & 0.036 & 0.180 & $<0.01$ & $<0.01$ & 0.073 & $<0.01$ & $<0.005$ & $<0.005$ & $<0.005$ & 0.008 \\
\hline
\end{tabular}

$<\mathrm{x}$ - below detection limit $\mathrm{x}$; NA - not analysed; *sum of p,p'DDE,-DDD,-DDT; \#sum of maneb, thiuram, zineb, metiram, mancozeb determined as $\mathrm{CS}_{2}$. Bold substances listed in the ME ordinance (Rozporządzenie 2016). 
Bioavaliability measurements (Baczynski et al. 2012) by solid phase extraction were carried out in a similar manner as described by Cornelissen et al. (1997). $1 \mathrm{~g}$ of soil was shaken with $30 \mathrm{ml}$ of $0.01 \mathrm{M}$ $\mathrm{CaCl}_{2}$ and $15 \mathrm{mg}$ of sodium azide (microbial inhibitor) added, and with $0.5 \mathrm{~g}$ of Tenax TA beads (20-35 mesh). At 1, 3, 6, 10, 24, 48 and 72 h Tenax was replaced with a fresh one. The used Tenax was extracted each time with $16 \mathrm{ml}$ of hexane for $15 \mathrm{~min}$. Extracts were analyzed by GC, after spiking with decachlorobiphenyl (PCB209) as a surrogate standard, followed by dilution to GC calibration range. Soil slurry was analyzed after $72 \mathrm{~h}$ for remaining pesticides. The slurry was filtered through a paper filter. The filtrate was spiked with PCB209 and extracted by shaking with $16 \mathrm{ml}$ of hexane. Air dried residue on a filter, spiked with surrogate standard, was heated for $4 \mathrm{~h}$ at $70^{\circ} \mathrm{C}$ with $16 \mathrm{ml}$ of hexane/acetone in closed vials. The cooled extract was centrifuged and dried with a small amount of anhydrous sodium sulfate. Extracts were diluted with hexane, if required by the GC calibration range. GC analyses were performed on a Carlo-Erba MEGA instrument with ECD and Stx-500 capillary column, with hydrogen as a carrier gas. Results were corrected using surrogate standard analyses for blank samples of appropriately diluted PCB209 and recovery factors.

Cumulated results of pesticide concentration desorbed by Tenax $S_{t}$ vs desorption time $t$ were fitted to a two-compartment desorption kinetics model:

$S_{t} / S_{0}=F_{\text {rapid }} \cdot \exp \left(-k_{d, \text { rapid }} \cdot t\right)+F_{\text {slow }} \cdot \exp \left(-k_{d, \text { slow }} \cdot t\right)$,

where:

$S_{0}$ - the total concentration (cumulative desorbed in $72 \mathrm{~h}+$ remaining in the slurry after $72 \mathrm{~h}$ ),

$F_{\text {rapid }}, F_{\text {slow }}$ - rapidly and slowly desorbing fraction of pesticide $($ sum $=1)$,

$k_{d, \text { rapid }}, k_{d, \text { slow }}-$ desorption rate constants for these fractions.

SPE tests were done with 3 or 4 replicates, and analyzed for concentration of p,p'-DDT; $\gamma-\mathrm{HCH}$ and methoxychlor. This laborious procedure was only undertaken for selected samples SEP2, SEP5, BOG5 and MLY2.
Phytotoxicity was tested using a Phytotox kit (manufacturer: Microbiotest; complying with ISO 11269-1). 10 seeds of Sorghum saccharatum (sorghum), Lepidium sativum (cress) or Synapis alba (mustard) were placed in plastic test containers filled with pre-wet soil. Root length was measured after 3 days of incubation. Tests were performed with 3 replicates for each plant.

Earthworm acute toxicity (PN-ISO 11268-1, similar to OECD 207) was carried out in $1 \mathrm{~L}$ containers using 10 adult Eisenia foetida worms each time. The number of dead and surviving worms was counted after 7 and 14 days. Tests were run with 3 or 4 replicates (number of replicates was consistent within tests series for each individual tomb).

Earthworm reproduction (PN-ISO 11268-2, similar to OECD 222) was done in $2 \mathrm{~L}$ vessels with 10 adult worms, fed weekly with ground cattle manure. Cocoons and hatched juveniles were counted after 28 and 56 days, respectively. This test was run in 4 replicates for SEP02, SEP4, SEP5, BOG02, BOG3, BOG5 samples, previously exhibiting no acute toxicity towards earthworms vs artificial soil.

Earthworm avoidance test was performed in a two-section setup (as in ISO 17512-1), using $2 \mathrm{~L}$ vessels. Half of the vessel was filled with the control soil, and the second part with the investigated sample. Then, 10 adult worms were placed on the division line. After $48 \mathrm{~h}$ the number of earthworms remaining in each section was counted. The series for this test were run with 3-5 replicates.

Microtox Solid-Phase Test of acute toxicity towards luminescent bacteria Vibrio fischeri was performed according to the manufacturer's (Azur Environmental) instructions. In short, microorganisms were put in direct contact with soil slurry in a duplicate series of dilution. After $20 \mathrm{~min}$, luminescence was measured in the filtrate using the Microtox Model 500 instrument. Results were automatically calculated to give $\mathrm{EC}_{50}$ - concentration of soil that causes $50 \%$ reduction of luminescence, with a $95 \%$ confidence interval. This test was performed once for each of the contaminated samples, and twice for background samples (artificial soil was not tested). 
Statistical analysis was performed with the use of the Kruskal-Wallis non-parametric test, due to a small size of groups, or data not meeting the assumptions required for parametrical analyses, such as homogeneity of variance.

\section{RESULTS}

Results of the analytical determination of pesticide residues in soil samples are listed in Table 1. Apart from the previously mentioned compounds, several other pesticides were analyzed but not found (diazionon, dichlorphos, malathion, methyl paration, thiometon, atrazine, prometrine, carbaryl, carbofuran, dichlorprop, dicamba, mecoprop, tetradifon - limits of detection $0.005-0.1 \mathrm{mg} / \mathrm{kg}$ ).

The current Ordinance of the Minister of Environment (Rozporządzenie 2016) sets extremely low limits of allowable pesticide concentrations for the layer below $0.25 \mathrm{~m}$ depth, if the soil is considered permeable. Admittedly, the hydraulic conductivity was not determined in the presented research but judging by the sandy texture of BOG and MLY samples, at least at these sites the limit $10^{-7} \mathrm{~m} / \mathrm{s}$ set in the Ordinance was probably exceeded. This means that all the collected samples should be regarded as polluted, including the background ones (mainly due to the low limits set for $\gamma$-HCH and p,p'-DDX: 0.001 and $0.025 \mathrm{mg} / \mathrm{kg}$, respectively). However, bearing in mind that a battery of bioassays was used to test the habitat function of soil (e.g. after its surface disposal following excavation), adopting standards for the surface $(0-0.25 \mathrm{~m})$ layer for agricultural areas seems to be a more realistic assessment of individual sample contamination. Then, only the SEP02 sample exhibits slightly raised $\gamma-\mathrm{HCH}$ concentration. In fact, the background samples, possibly with the latter exception, could not be regarded as polluted to a meaningful extent because, according to Maliszewska et al. (2014), $27 \%$ of arable soils in Poland exhibited a p,p'-DDX concentration above $0.05 \mathrm{mg} / \mathrm{kg}$, and such a level is not considered hazardous in other countries. $12 \%$ of soils in Poland contained more than $0.01 \mathrm{mg} / \mathrm{kg}$ of $\gamma-\mathrm{HCH}$ which, however, may be of some concern.

With such an approach, samples from the BOG site could be characterized as moderately contaminated, due to $\mathrm{p}, \mathrm{p}^{\prime}-\mathrm{DDX}$ and $\gamma-\mathrm{HCH}$ concentrations exceeding permissible limits by a number of times. The most polluted was the BOG4 soil, not only because in this case $\gamma-\mathrm{HCH}$ was almost 70 times higher than the respective limit, but also containing residues of several other insecticides, especially organophosphates, nitrophenol herbicide dinoseb and fungicide quintozene (pentachloronitrobenzene) - all not included in the present standard.

More seriously polluted were the SEP samples, with limits for p,p'-DDX; $\gamma$-HCH and dithiocarbamates (fungicides) overrun by tens to hundreds times. Samples could be ranked from the least to most contaminated as: SEP4 < SEP5 < SEP2, not only according to increasing concentrations of the pesticides mentioned above (esp. the two last ones), but also other non-standardized compounds, belonging to herbicide class: nitrophenols dinoseb and dinitroortocresol (DNOC), phenoxy acids 2,4-D and MCPA, simazine, chloropropham and fungicide quintozene.

With reference to p,p'-DDX, the contamination of the MLY samples was even higher that samples from SEP site, and an increasing level of pollution was found as: MLY2 < MLY4 < MLY3. The most polluted sample MLY3 also contained several other chlorinated compounds: cyclodienes dieldrin and endrin, $\alpha$ - and $\gamma-\mathrm{HCH}$ isomers (from a few to hundreds of times above the respective standards). There were also significant amounts of methoxychlor, dithiocarbamates, herbicide DNOC, and insecticide propoxur present. Some compounds not listed in the Ordinance were also detected in other samples from this tomb area, in concentrations comparable or lower.

Results of the Tenax SPE (Fig. 2) indicated that, despite quite a long contact time with soil (around 30 years), still a major part of contaminants: p,p'-DDT; $\gamma$-HCH and methoxychlor, remained easy available (desorbable) at all sites. The exception was only the BOG5 sample, where rapidly desorbing fractions of p,p'-DDT and methoxychlor were small (33.9\% and 24.8\%), as opposed to $\gamma-\mathrm{HCH}(91.1 \%)$. The reason behind this was probably the less hydrophobic character of $\gamma-\mathrm{HCH}$, which makes is less prone to sequestration ("aging") in soil. It should be noted that both the samples from the SEP site were quite close in terms of the magnitude of the rapidly desorbing fractions for each individual compound (Baczynski et al. 2012). 


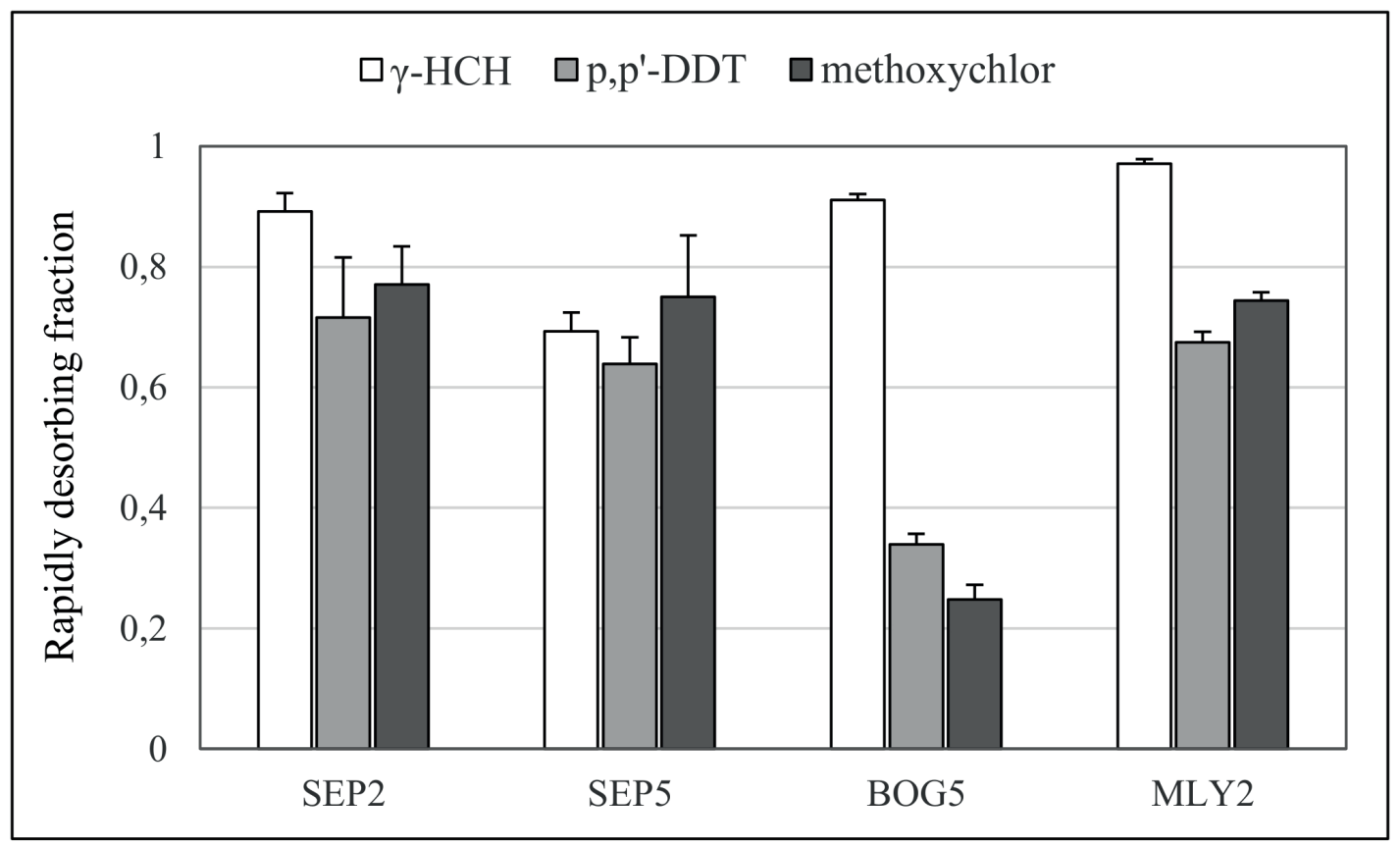

Fig. 2. Results of the Tenax SPE analysis - rapidly desorbing fraction of pesticides. Error bars - standard deviation (also in other figures)

Data from Phytotox tests are presented in Figure 3. It can be noted that background samples caused some inhibition (like SEP02) or, on the contrary, the stimulation of root growth (BOG02, MLY02) compared to the REF soil. However, these differences were found to be statistically significant $(p<0.05)$ only for mustard and only in the case of SEP02. Contaminated samples from the SEP site strongly suppressed root growth - comparing to REF there was 95-99.5\% reduction for cress, $92-100 \%$ for mustard, and $66-91 \%$ for sorghum. With reference to SEP02, the respective numbers were: $61-96 \%, 59-100 \%$ and $34-82 \%$. SEP2 and SEP5 samples exhibited significant differences both against REF and background for all tested plants. Inhibition was less intensive at the BOG site, especially for BOG3 and BOG5, and average root length was $22-98 \%$ smaller for cress, -2 (stimulation)-99\% for mustard, and $15-97 \%$ for sorghum, in relation to REF. Comparing to background BOG02, the detected decrease was, respectively: 7-98\%, 13-99\% and -32(stimulation)-21\%. Results for BOG4 (cress and mustard), and for BOG3 (mustard) were significantly different $(p<0.05)$ towards both REF and BOG02. Regarding the contaminated MLY samples, strong negative effects were evident again, despite the apparently favorable background soil conditions. Cress growth was smaller by $84-99 \%$, mustard $65-99 \%$, sorghum $41-72 \%$, compared to REF. Assuming the background as reference, the reduction was even greater, respectively $89-99 \%, 82-99 \%$ and $87-94 \%$. Significant differences against both REF and MLY02 were found for all plants and for all samples (MLY2, MLY3 and MLY4).

Results of earthworm acute toxicity as a percentage of surviving individuals after incubation time are given in Figure 4. Assuming the toxicity criterion (Hund-Rinke \& Wiechering 2001) as mortality rate $>20 \%$ ( $<80 \%$ still alive) samples SEP2, BOG4 and all samples from MLY site should be considered as toxic. However, in the latter case, this could probably be ascribed to some unfavorable properties of the soil, as $100 \%$ mortality also occurred in the background sample MLY02. Contaminants might only intensify this effect. It should also be noted that for the SEP5 sample several sub-lethal symptoms were observed: weight loss, abnormal behavior and appearance. 


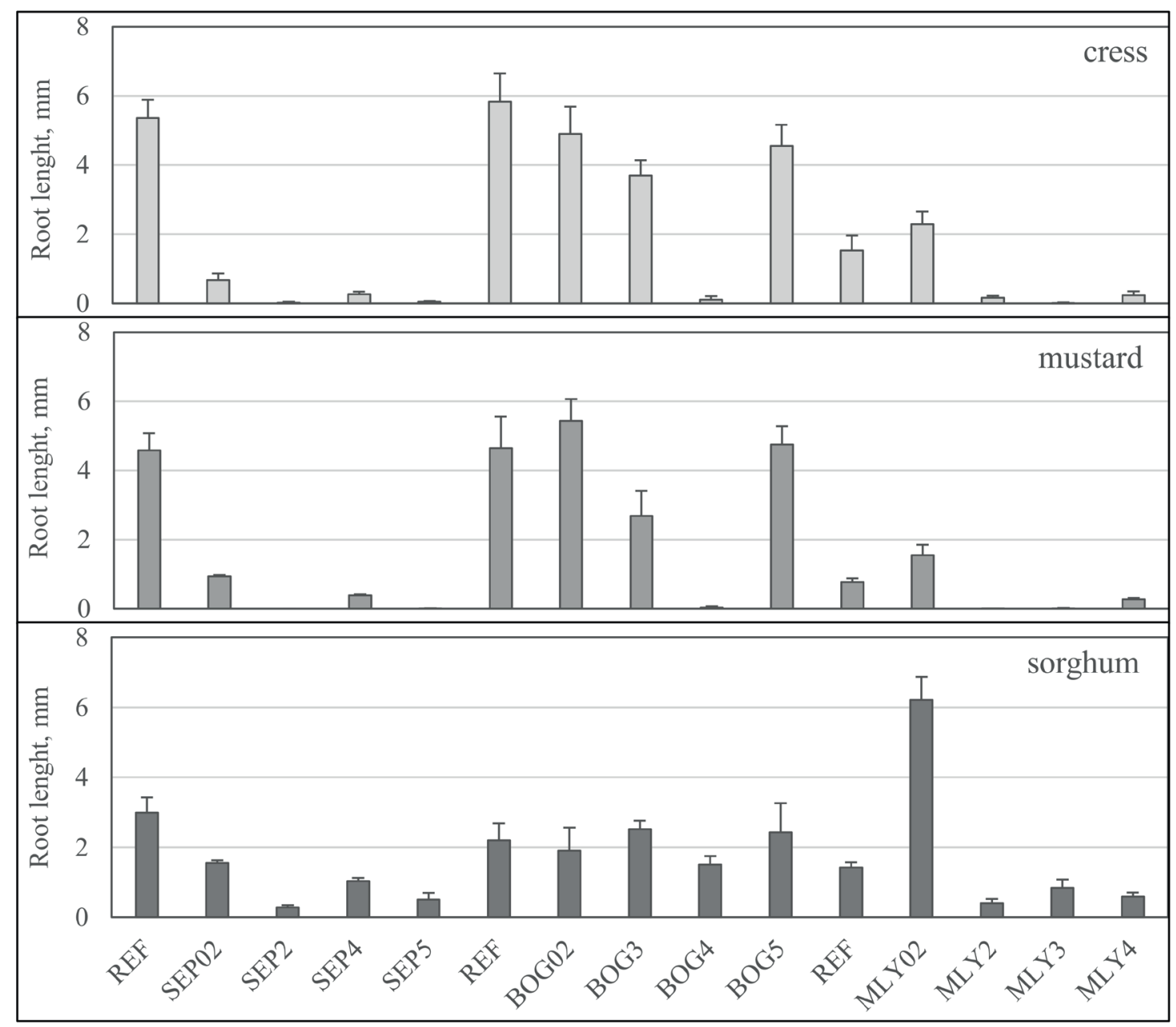

Fig. 3. Phytotox bioassays - root length after 3 days of incubation

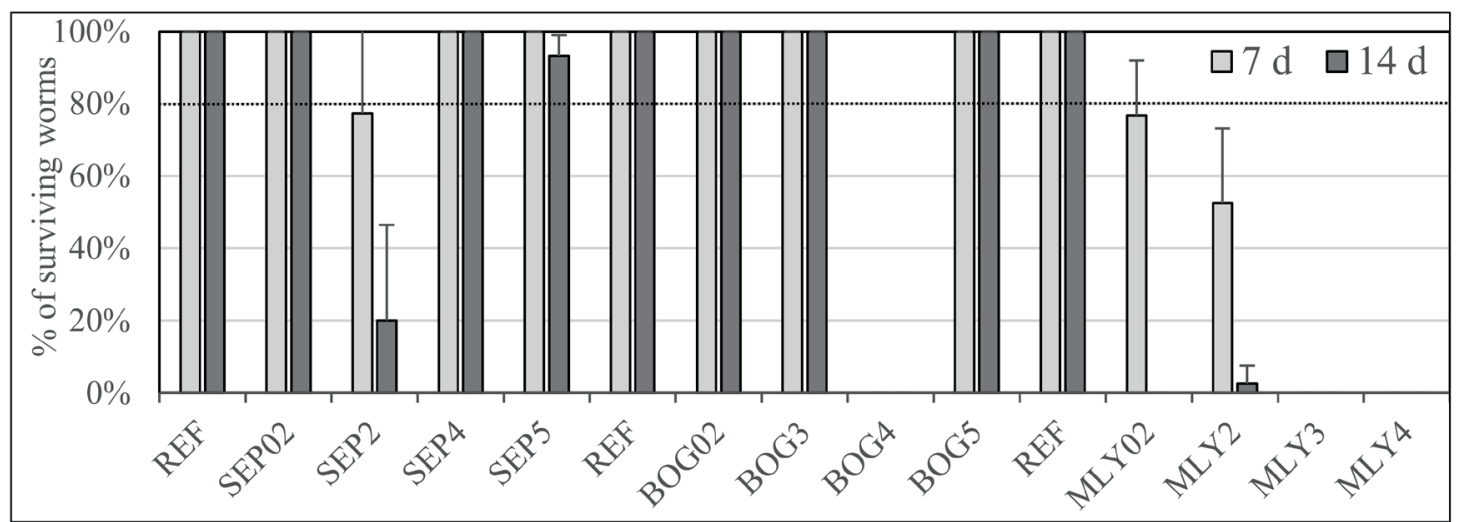

Fig. 4. Results of the earthworm acute toxicity test: percentage of surviving worms

Chronic toxicity (reproduction test) was investigated for all samples which were not acutely toxic. However, in the SEP4 and SEP5 samples, all the worms were found to be dead before the end of the test, demonstrating a delayed acute effect. In the background sample SEP02, the number of cocoons and juveniles were respectively $60 \%$ and $63 \%$ lower than for REF. The results for soils from 
the BOG site are presented in Table 2. A considerable decrease in the number of cocoons and hatched juveniles produced is noticeable for contaminated samples BOG3 and BOG5, both in reference to REF or BOG02 soil. Nevertheless, the only statistically significant difference occurred between REF and BOG5 samples (cocoons and juveniles), pointing to the most intensive effect. Also, only in this sample more than $50 \%$ reduction of offspring took place (compared to the background BOG02), indicating its toxicity (Hund-Rinke \& Wiechering 2001). Assuming REF as a control, such a reduction occurred both in the BOG3 and BOG5 samples.

Table 2

Results of the earthworm reproduction test for the BOG samples: percentage of reduction comparing to REF and BOGO2

\begin{tabular}{|l|c|c|c|c|}
\hline \multirow{2}{*}{ Sample } & \multicolumn{2}{|c|}{ Against REF } & \multicolumn{2}{c|}{ Against BOG02 } \\
\cline { 2 - 5 } & cocoons & juveniles & cocoons & juveniles \\
\hline BOG02 & $32.1 \%$ & $47.6 \%$ & - & - \\
\hline BOG3 & $64.3 \%$ & $67.4 \%$ & $47.4 \%$ & $37.9 \%$ \\
\hline BOG5 & $68.6 \%$ & $89.3 \%$ & $53.7 \%$ & $79.5 \%$ \\
\hline
\end{tabular}

Results of earthworm avoidance bioassays are shown in Figure 5. Assuming, that $<20 \%$ worms remaining in the tested soil indicates a limitation of its habitat function (Hund-Rinke \& Wiechering 2001), such a criterion was met for samples SEP2 and SEP5, and all of the contaminated soils from the BOG tomb, if compared to REF. BOG02 and MLY3 were slightly above this limit. In such a setup, statistically significant differences occurred only between the background BOG02 and the polluted samples from this site: BOG4 and BOG5. However, if the background sample from the respective site was taken as a control in each series (an approach more representative in terms of the soil properties), the earthworms clearly avoided only the most contaminated samples of SEP2 and BOG4; SEP5 was only a little above the avoidance limit. Significant differences were found between the little avoided sample SEP4 and the rest from this tomb, favored BOG3 and other contaminated samples from this site, and also between BOG02 and BOG4 (completely avoided).

As for the SEP site, the only reliable Microtox results were obtained for background SEP02 and SEP5. For SEP2 and SEP4, the results were questionable due to an intensive coloration of the filtrate, preventing luminescence readouts, and probably resulting from the type of soil (weathered clay with a large fine particle fraction). Such a problem was not encountered for sandy BOG and MLY soils. All of the results are given in Figure 6. Attention should be paid to the two issues: firstly, a large, one order of magnitude difference between $\mathrm{EC}_{50}$ for background samples from the separate sites. Secondly, repeated measurements for the background from the same site differed almost 2-3 times, pointing to the moderate repeatability of this biotest. Thus, results lower 1-2 orders of magnitude that respective background, reliably demonstrating toxic properties, were obtained only for more severely contaminated samples (all MLY, SEP5 and BOG4).

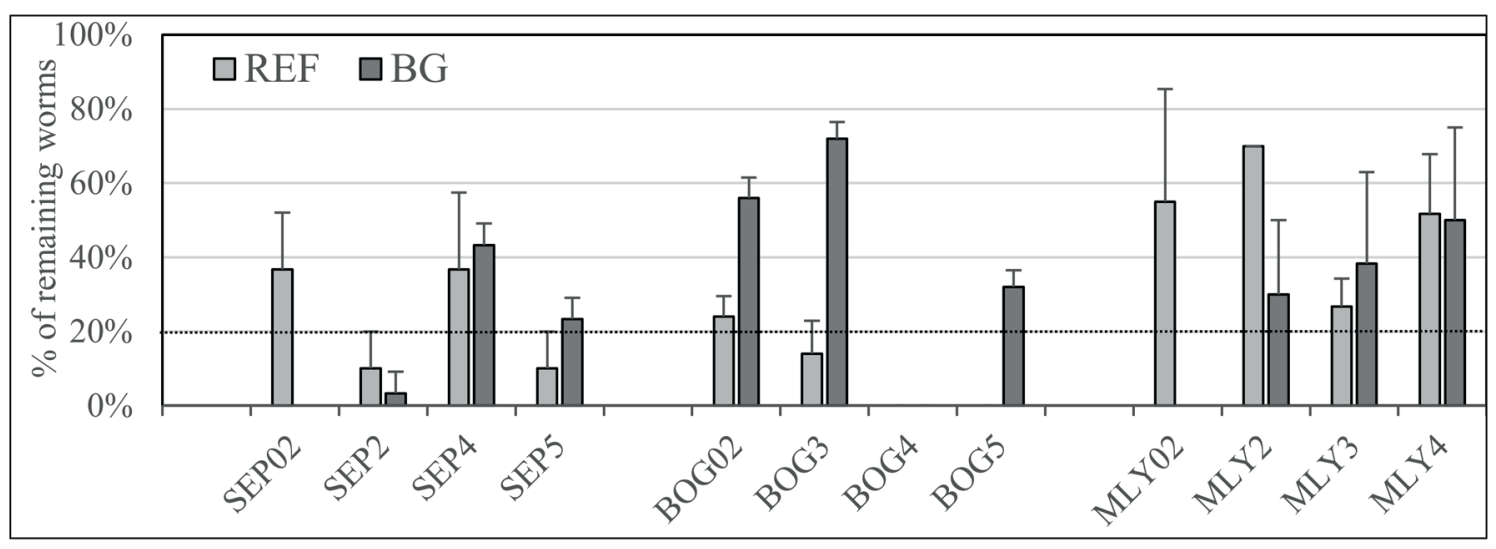

Fig. 5. Results of the earthworm avoidance test: percentage of worms remaining in the tested sample (REF against reference soil, $B G$ against background sample) 


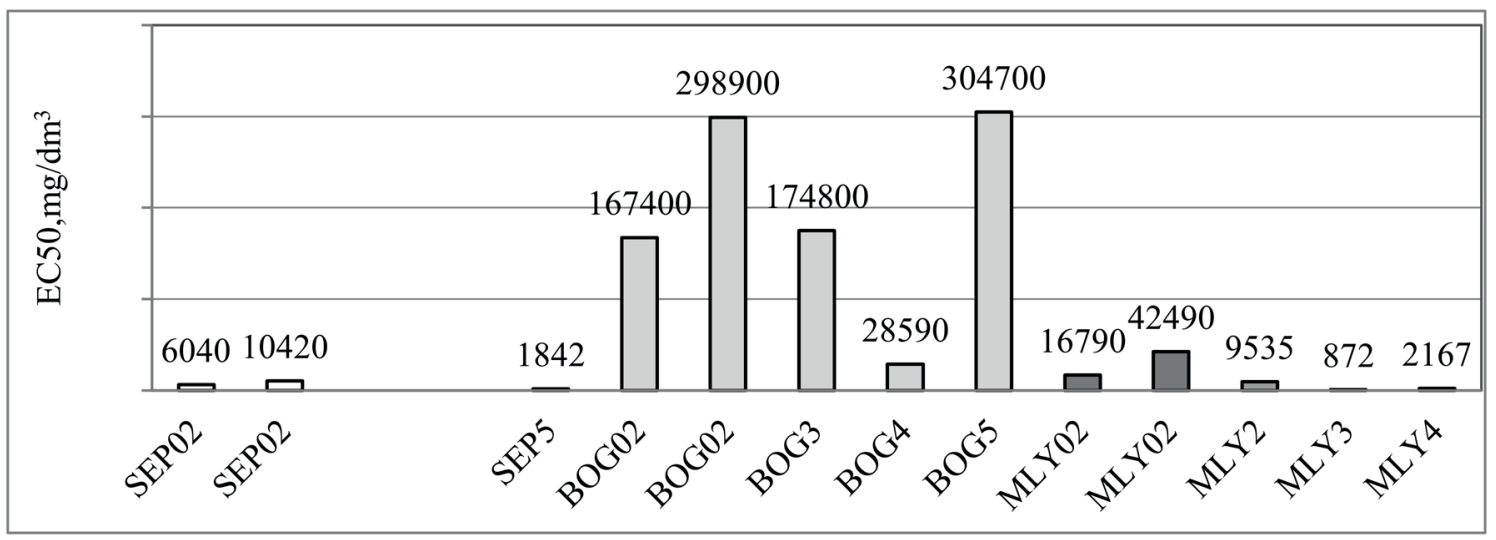

Fig. 6. Results of the Microtox Solid Phase test: $E C_{50}$

\section{DISCUSSION}

The battery of performed bioassays clearly demonstrated that for the all tested contaminated soils, the habitat function was seriously damaged. The only exception might be the BOG3 sample, where only some limitation towards root growth (mustard) took place, and sample BOG5, with some suppression of earthworm reproduction. Both samples were polluted only with p,p'-DDX and $\gamma-\mathrm{HCH}$, with respective limits exceeded by only a few times. Moreover, Tenax SPE indicated that at least some pesticides could be less bioavailable at the BOG site, and thus less harmful.

It should be stressed, however, that analytical assessment, based exclusively on the list of compounds and limits set in the respective Polish soil standard (Rozporządzenie 2016), did not indicate the intensity of soil habitat function damage. The apparently not so polluted BOG4 soil, in terms of standardized chemicals - p,p'-DDX and $\gamma-\mathrm{HCH}$, showed similar severe phyto- and zootoxicity than the far more contaminated samples from SEP and MLY sites. This points to the necessity of bioassay use in any ecotoxicological risk assessment to complement chemical analyses.

In all of the contaminated soil samples, almost all of the compounds were found at concentrations at least one order of magnitude lower than their $\mathrm{LC}_{50}$ toward Eisenia foetida earthworms (according to data from Lewis et al. 2016). For example, $\mathrm{LC}_{50}$ for $\mathrm{p}, \mathrm{p}$-DDT is given as $>1000 \mathrm{mg} / \mathrm{kg}$, for $\gamma-\mathrm{HCH}$ as $68 \mathrm{mg} / \mathrm{kg}$; and $\mathrm{LC}_{50}$ for mancozeb, the most toxic of dithiocarbamates, is $299 \mathrm{mg} / \mathrm{kg}$. Limited acute toxicity of p,p'-DDT against $E$. foetida is also confirmed by Shi et al. (2016), who estimated its $14 \mathrm{~d}$ median lethal concentration $\left(\mathrm{LC}_{50}\right)$ to $273.8 \mathrm{mg} / \mathrm{kg}$ soil. Thus, it seems that only in sample MLY3 p,p'-DDT might have contributed to the observed mortality. Another pesticide that could be individually suspected as potentially responsible for some toxic effects was DNOC, with its $\mathrm{LC}_{50}$ given as $16 \mathrm{mg} / \mathrm{kg}$ (Lewis et al. 2016). DNOC was present in all contaminated MLY samples and SEP2, reaching $23-43 \%$ of this toxicity threshold, and concurrently these samples exhibited severe acute toxicity. In the SEP2 sample, the lethal effect could have been intensified by the presence of $9.6 \mathrm{mg} / \mathrm{kg} 2,4-\mathrm{D}$ (Correia \& Moreira 2010). However, the BOG4 sample was also very toxic, with all pesticide concentrations far below values that could be concerned as really harmful. The same refers to samples SEP4 and SEP5, also exhibiting some poisonous properties. Therefore, it seems that in the presented case soil toxicity toward earthworms resulted rather from the synergistic effect of the mixture of several chemicals than the action of any single compound. It also cannot be excluded, given the complex nature of the pollution at the tombs, that there could be some unidentified (not analyzed) metabolites, and/or other chemicals present, like agents used in commercial formulations of pesticides, e.g. toluene or other solvents.

The reproduction test was proven to be more sensitive than acute toxicity bioassay, exhibiting 
not only delayed mortality (SEP4 and SEP5), but also allowing the more precise distinction of soil harmful properties in the case of the slightly polluted samples BOG3 and BOG5. Other reproduction tests, e.g. with springtails (Collembola) can also be indicative of pesticide pollution (El-Temsah \& Joner 2013).

The extent of the earthworm behavioral response (avoidance) generally conformed with the pollution level of samples within the sites' series. However, the diagnostic value of this test was found to be limited. As a matter of fact, all of the soils which were clearly avoided (less than $20 \%$ remaining worms, SEP2, SEP5, BOG4) exhibited short or long term acute toxicity. Also, samples BOG3 and BOG5, which were avoided only when REF was an alternative, showed some effects on earthworm reproduction. Yet this was not the case in the opposite direction - for the acutely toxic MLY samples and the SEP4 sample (the latter with a delayed effect) the avoidance criterion was not met. Therefore, it seems that the avoidance response might be useful only as a screening test, with non-avoided samples ( $>20 \%$ remaining worms) forwarded to further testing, as stated also by Hund-Rinke \& Wiechering (2001). Attention must also be paid to the fact that soil properties can influence the result of such tests, which was also noticeable in this study. For example, according to Natal-da-Luz et al. (2008) earthworms avoided soils with a low carbon content and a fine texture.

The occurrence of phytotoxic effects should primarily be ascribed to the presence of herbicide residues: nitrophenols, phenoxy acids, simazine or chloropropham. It should be pointed out that the only samples where root growth suppression was absent or minimal were BOG3 and BOG5, where such compounds were not detected. As for the remaining polluted samples, an overall more intense influence was found in samples with higher concentrations of these chemicals. The generally observed greater inhibition towards cress and mustard probably resulted from the presence of selective herbicides, like 2,4-D; MCPA, which suppress the growth of dicotyledonous plants. Their effectiveness is very high, e.g. for 2,4-D or MCPA $\mathrm{EC}_{50}$ for cress and mustard root growth are in the range of tenth of milligram per liter/kilogram
(Grabińska-Sota et al. 2003, Sekutowski \& Sadowski 2009). Other compounds such as dinoseb, DNOC, and simazine were also used to control broad-leaved weeds $\left(\mathrm{EC}_{50}\right.$ of DNOC for cress: $3.9 \mathrm{mg} / \mathrm{dm}^{3}$; Bettiol et al. 2016). It should be noted that matrix (soil) properties, such as $\mathrm{pH}$, nutrients etc. might affect the results of phytotoxicity tests as well, something which was visible for background samples.

Microtox Solid Phase tests turned out to be more problematic than the other bioassays used. Although the bacteria Vibrio fischeri appears to be quite sensitive toward pesticides (perhaps more than earthworms - some $\mathrm{EC}_{50}$ from literature: p,p'-DDT $39 \mathrm{mg} / \mathrm{dm}^{3} ; \gamma-\mathrm{HCH} 48 \mathrm{mg} / \mathrm{dm}^{3} ; 2,4-\mathrm{D}$ $22 \mathrm{mg} / \mathrm{dm}^{3}$; DNOC $5.7 \mathrm{mg} / \mathrm{dm}^{3}$; Gosh et al. 1997, Bettiol et al. 2016), the results of this test are also largely influenced by soil composition and color, as shown in this study. Similar problems have been reported and addressed by others, e.g. Ringwood et al. (1997), Campisi et al. (2005), Pérez et al. (2012). Another disadvantage mentioned above was the poor repeatability, as stated for background samples. Because of that, $\mathrm{EC}_{50}$ results clearly and reliably indicating toxicity have to be considerably lower than controls, which could be obtained only for very contaminated samples.

\section{CONCLUSIONS}

The biotest battery used in the current study, clearly indicated a diverse impairment of habitat function in the tested pesticide contaminated soil samples (from slight to severe). Results of chemical analysis of pesticide residues, especially if limited solely to compounds listed in the current Polish soil quality standard, gave only a partial indication of such ecotoxicological risk. Biotests were complementary in this respect.

As for individual bioassays, Phytotox, earthworm acute toxicity and reproduction tests were found to be reliable and very sensitive, especially the last one. Earthworm avoidance tests were found to be useful rather as the screening test, indicating samples requiring further investigation. The Microtox Solid Phase test was of a limited value, due to several problems encountered such as repeatability, influence of soil composition and its color. However, despite these difficulties, this test 
was also able to demonstrate the toxicity of more polluted samples.

Results of all of the used tests appeared to have been affected to various degrees by the soil properties, apart from its pollution. Therefore, it seems advisable to use, if possible, uncontaminated background soil as a control rather than artificial reference soil.

The presented work was performed within the projects 3 T09D 04928 and PB 4524/T02/2009/36, financed by the Polish Committee for Scientific Research and the Ministry of Science and Higher Education.

\section{REFERENCES}

Baczynski T.P., Pleissner D. \& Krylow M., 2012. Bioremediation of chlorinated pesticides in field-contaminated soils and suitability of Tenax solid-phase extraction as a predictor of Its effectiveness. CLEAN-Soil, Air, Water, 40, $8,864-869$

Baczyński T., 2010. Bioremediacja gruntów zanieczyszczonych pestycydami chlorowanymi: przegląd technologii zastosowanych w pełnej skali. Przemyst Chemiczny, 89, 1, 61-65.

Bettiol C., De Vettori S., Minervini G., Zuccon E., Marchetto D., Ghirardini A.V. \& Argese E., 2016. Assessment of phenolic herbicide toxicity and mode of action by different assays. Environmental Science and Pollution Research, 23, 8, 7398-7408.

Bojakowska I., Tomassi-Morawiec H. \& Markowski W., 2018. PAHs and DDTs in soil and sediment of inland water bodies of Warsaw city and its surroundings. Journal of Geochemical Exploration, 187, 57-71.

Campisi T., Abbondanzi F., Casado-MartinezC., DelValls T.A., Guerra R. \& Iacondini A., 2005. Effect of sediment turbidity and color on light output measurement for Microtox ${ }^{\oplus}$ Basic Solid-Phase Test. Chemosphere, 60, 1, 9-15.

Cornelissen G., van Noort P. \& Govers H.A., 1997. Desorption kinetics of chlorobenzenes, polycyclic aromatic hydrocarbons, and polychlorinated biphenyls: sediment extraction with Tenax ${ }^{\circ}$ and effects of contact time and solute hydrophobicity. Environmental Toxicology and Chemistry, 16, 7, 1351-1357.

Correia F.V. \& Moreira J.C., 2010. Effects of glyphosate and 2, 4-D on earthworms (Eisenia foetida) in laboratory tests. Bulletin of Environmental Contamination and Toxicology, 85, 3, 264-268.

El-Temsah Y.S. \& Joner E.J., 2013. Effects of nano-sized zero-valent iron (nZVI) on DDT degradation in soil and its toxicity to collembola and ostracods. Chemosphere, 92, 1, 131-137.

Gałuszka A., Migaszewski Z.M. \& Manecki P., 2011. Pesticide burial grounds in Poland: a review. Environment International, 37, 7, 1265-1272.

Ghosh S.K., Doctor P.B., Bhatnagar V.K., Yadav S., Derasari A., Kulkarni P.K. \& Kashyap S.K., 1997. Response of three microbial test systems to pesticides. Bulletin of Environmental Contamination and Toxicology, 58, $3,482-488$.

Grabińska-Sota E., Wiśniowska E. \& Kalka J., 2003. Toxicity of selected synthetic auxines - 2, 4-D and MCPA derivatives to broad-leaved and cereal plants. Crop Protection, $22,2,355-360$.

Hund-Rinke K. \& Wiechering H., 2001. Earthworm avoidance test for soil assessments. Journal of Soils and Sediment, 1, 1, 15-20.

Jensen J. \& Mesman M., 2006. Ecological risk assessment of contaminated land - Decision support for site specific investigations. RIVM Report 711701047.

Kim K.H., Kabir E. \& Jahan S.A., 2017. Exposure to pesticides and the associated human health effects. Science of The Total Environment, 575, 525-535.

Lewis K.A., Tzilivakis J., Warner D. \& Green A., 2016. An international database for pesticide risk assessment and management. Human and Ecological Risk Assessment: An International Journal, 22, 4, 1050-1064.

Małachowska-Jutsz A., Baczyński T. \& Stobiecki T., 2007a. Badania toksyczności gruntów z terenów składowisk nieprzydatnych środków ochrony roślin. [in:] Ekotoksykologia $w$ ochronie środowiska glebowego i wodnego: pierwsza krajowa konferencja $i$ warsztaty naukowe: materiały konferencyjne, 14-16 października 2007, IUNG-PIB, Puławy, Instytut Uprawy, Nawożenia i Gleboznawstwa - Państwowy Instytut Badawczy, Puławy, 80-83.

Małachowska-Jutsz A., Kalka J., Chromy D. \& Baczyński T., 2007b. Ocena toksyczności gruntu zanieczyszczonego odpadami popestycydowymi $\mathrm{w}$ rejonie mogilnika Sepno-Radonia. Inżynieria i Ochrona Środowiska, 10, 4, 293-307.

Małachowska-Jutsz A., Kalka J. \& Baczyński T., 2008. Contamination of soil by pesticide wastes - a case study. Fresenius Environmental Bulletin, 17, 12b, 2200-2206.

Maliszewska-Kordybach B., Smreczak B. \& Klimkowicz-Pawlas A., 2014. Evaluation of the Status of Contamination of Arable Soils in Poland with DDT and HCH Residues; National and Regional Scales. Polish Journal of Environmental Studies, 23, 1, 139-148.

MŚ, 2016. Odpowiedź na interpelację K8INT3186 w sprawie monitoringu terenów po zlikwidowanych mogilnikach. Ministerstwo Środowiska, Warszawa, [on-line:] www.sejm.gov.pl/Sejm8.nsf/InterpelacjaTresc.xsp?key= 77F95787 [access: 29.09.2017].

Natal-da-Luz T., Römbke J. \& Sousa J.P., 2008. Avoidance tests in site-specific risk assessment - influence of soil properties on the avoidance response of collembola and earthworms. Environmental Toxicology and Chemistry, $27,5,1112-1117$.

NIK, 2012. Informacja o wynikach kontroli. Realizacja „Krajowego Planu Gospodarki Odpadami 2010” w zakresie likwidacji mogilników. Najwyższa Izba Kontroli. Delegatura w Białymstoku, Białystok, [on-line:] https://www. nik.gov.pl/plik/id,3758,vp,4852.pdf [access: 29.09.2017].

Odukkathil G. \& Vasudevan N., 2013. Toxicity and bioremediation of pesticides in agricultural soil. Reviews in Environmental Science and Bio/Technology, 12, 4, 421-444.

Pérez K.F.B., Charlatchka R., Sahli L. \& Férard J.F., 2012. New methodological improvements in the Microtox ${ }^{\circ}$ solid phase assay. Chemosphere, 86, 1, 105-110. 
Ringwood A.H., DeLorenzo M.E., Ross P.E. \& Holland A.F., 1997. Interpretation of Microtox ${ }^{\bullet}$ solid-phase toxicity tests: The effects of sediment composition. Environmental Toxicology and Chemistry, 16, 6, 1135-1140.

Rozporządzenie, 2016. Rozporzadzenie Ministra Środowiska $z$ dnia 1 września 2016 r. w sprawie sposobu prowadzenia oceny zanieczyszczenia powierzchni ziemi. Dz.U. 2016, poz. 1395.

Sekutowski T. \& Sadowski J., 2009. Phytotoxkit TM microbiotest used in detecting herbicide residue in soil. Environment Protection Engineering, 35, 1, 105-110.

SIDoM, 2010. System Integracji Danych o Mogilnikach. Narodowy Fundusz Ochrony Srodowiska i Gospodarki Wodnej, Ministerstwo Środowiska, Warszawa, [on-line:] http:// mogilniki.pgi.gov.pl/mogilniki/ [access: 26.04.2018].
Siebielec G. et al., 2017. Raport z III etapu realizacji zamówienia „Monitoring Chemizmu Gleb Ornych w Polsce w Latach 2015-2017”. Instytut Uprawy, Nawożenia i Gleboznawstwa - Państwowy Instytut Badawczy, Puławy, [on-line:] http://www.gios.gov.pl/images/dokumenty/ pms/monitoring_jakosci_gleb/Raport_MChG_etap3. pdf [access: 29.09.2017].

Shi Y., Zhang Q., Huang D., Zheng X. \& Shi Y., 2016. Survival, growth, detoxifying and antioxidative responses of earthworms (Eisenia fetida) exposed to soils with industrial DDT contamination. Pesticide Biochemistry and Physiology, 128, 22-29.

Ustawa, 2018. Ustawa z dnia 27 kwietnia 2001 r. Prawo ochrony środowiska. Dz.U. 2001, nr 62, poz. 627; consolidated text: Dz.U. 2018, poz. 799. 